\title{
ANALYSIS OF MARKET PROFESSIONAL SERVICES IN UKRAINE
}

\section{N. Zhmurko}

\author{
Ivan Franko National University of Lviv \\ 79008, Lviv, Svoboda Avenue, 18 \\ e-mail:nata_zhmurko@ukr.net
}

The article considers the necessity and importance of the existence of the market of professional services, outlines the nature and purpose of the audit in accordance with the current legislation of Ukraine, the functions and role of the Audit Chamber of Ukraine. The peculiarities of the regulatory and institutional framework for the provision of services by audit firms in the context of international and domestic legislation are highlighted.

The analysis of the presence of the world's largest auditing companies in Ukraine has revealed the representation of each of the ten financial giants in the domestic market. The historical and institutional background for the formation of an unfair competitive environment in this area is highlighted, where the largest share belongs to BIG FOUR companies. The reasons of monopolization of the market of providing of audit services are investigated and the factors hindering the establishment and functioning of small audit firms are outlined. An analytical review of audit activity in the state is carried out in terms of regions and types of services rendered.

Based on the research, it was discovered that the market for auditing services is diversified unevenly throughout the territory of Ukraine, in particular, the largest share of all audit companies belongs to the Kyiv region, where almost half of all participants of the market of professional services of the state are concentrated. On the basis of data evaluation over the last three years, a number of problems faced by the professional services market in Ukraine have been identified. On the basis of the analysis, the author developed S.W.O.T. analysis of the Ukrainian market of professional services.

The analysis clearly outlines all four aspects, namely: strengths of the Ukrainian professional services market, weaknesses in the provision of audit services, potential opportunities for functioning of this market both within Ukraine and the international market, as well as threats in recent years. It is proved that the unfavorable socioeconomic situation in Ukraine requires quality provision of audit services, as well as the development of the institutional and legal environment and conditions that will promote an equitable and equitable distribution of financial services.

Keywords: audit, financial (audit) services, market of professional services, audit companies, S.W.O.T. analysis.

Nowadays financial and economic spheres of Ukraine face a lot of problems and challenges. It seems that our country is passing some type of "exams" and must to prove

(C) N. Zhmurko, 2019 
that is definitely ready to be the strong part of European Union and be ready in creating the best conditions for life for Ukrainian people. Nevertheless that we have some progress in this examination we must be honest with ourselves - the problems are so deep and complicated, and the way upstairs is going to be heavy.

Ukraine's economy has contracted deeply and remains very fragile. Ongoing disruptions of the country's productive and export capacities and significant capital outflows have put increasing pressure on the currency and reserves, severely undermining monetary stability. The overall soundness of fiscal policy has deteriorated substantially, and public deficits and debt have increased sharply. The rule of law remains fragile and is further undercut by judicial ineffectiveness. A strong commitment to structural reforms to reduce corruption and open the economy further to Western investment and financial institutions will be crucial in helping to stabilize the economy. The government has launched a comprehensive set of reforms to restore growth, but progress is not yet evident... [16].

So this article presents regulatory, institutional and analytical information on how a market of professional services functions in Ukraine. In this, based on evaluation of data over the past three years, there have been identified and assessed a number of problems that a market of professional services in Ukraine faces. The article also includes a S.W.O.T. analysis of the Ukrainian market of the professional services.

The reliability and objectivity of valuation of the property of economic entities is the main reason for the emergence of the market of audit services in the world. Ukraine has not become an exception to these world trends. The mass privatization processes that took place in the early 1990's and the creation of private enterprises have been the impetus for the formation of the market of audit services and the adoption of the Law of Ukraine "About Audit Activity" issued on April 24, 1993. It's well known that with the adoption of this law began the formation of the audit services market, where the main services at that time had only two directions - professional consultations on the issues of proper accounting and financial reporting.

Accordingly to the article third of this law: "Audit activity - entrepreneurial activity, which includes the organizational and methodological provision of audit, the practical implementation of audits (audit) and provision other audit services". In order rise the development, improvement and unification of audit activity in 1993, was created an independent Institution - the Auditing Chamber of Ukraine, that [18]:

1) issues the certification of persons who intend to engage audit activity;

2) approve the audit standards;

3) approves the program of preparation of auditors and with the consent with the National Bank of Ukraine, a training program for auditors, which carry out an audit of banks;

4) maintains the Register;

5) supervises the compliance of audit firms and auditors of the requirements of this Law, standards of audit, norms of professional ethics of auditors;

6) carries out measures to ensure the independence of auditors at carrying out audits and overseeing them the quality of audit services;

7) regulates the relationship between auditors (auditors firms) in the process of carrying out audit activity and in this case necessity to apply to them a penalty;

8) carries out other powers stipulated by this Law and Statute of the Audit Chamber of Ukraine. 
Currently, the corporate financial reporting framework in Ukraine is governed by requirements outlined in the following legislations $[12,21]$ :

- Company Law (2004) - describes financial reporting requirements for Limited Liability Companies (LLCs) and Joint Stock Companies (JSCs).

- Law on Audit Activities (2003 with subsequent amendments) - stipulates entities subject to statutory audits, authorizes national regulator of the audit profession, the Auditing Chamber of Ukraine (ACU), to set auditing standards, and requires application of ISA. According to the Law, statutory audits are mandatory for JSCs, issuers of securities, bond issuers, professional securities market participants, financial institutions, insurance companies, and companies with foreign investment.

- Law on Accounting and Financial Reporting of 2000 stipulates that the overall development and implementation of accounting and financial reporting methodology is regulated by the Ministry of Finance of Ukraine (MoF). MoF is authorized to approve the National Accounting Standards (NASs) and other regulatory acts with respect to general accounting and financial reporting. Under this Law, Accounting Methodological Council (AMC), an advisory body under the Ministry of Finance was established to set NASs based on IASs/IFRS. The Law authorizes the National Securities and Capital Markets Commission) and the National Bank of Ukraine to set specific reporting requirements for their regulated entities.

- Law on Banks and Banking (2000 with subsequent amendments) - outlines accounting and auditing requirements for banks, defines the structure of the banking system, economic, organizational and legal fundamentals for establishment, regulation and operation of banks.

- Law on State Regulation of Securities Markets in Ukraine-establishes accounting and auditing requirements for the securities markets participants.

- Law on Financial Services and State Regulation of Financial Services Marketsstates the financial reporting requirements for non-banking financial institutions.

- Various Regulations issued by the ACU - to fulfill its mandate to regulate the profession.

Except of Audit Chamber of Ukraine, there are a few professional Accountancy Organizations in Ukraine:

1. The Ukrainian Federation of Professional Accountants and Auditors (UFPAA);

2. The Ukrainian Association of Certified Accountants and Auditors (UACAA);

3. The Union of Auditors of Ukraine (UAU);

4. The Federation of Auditors, Accountants and Financiers of the Agricultural and Industrial Complex of Ukraine (FAAF AICU);

5. The Council of Independent Accountants and Auditors (CIAA).

Since 2007, auditors were given the opportunity to legally evaluate, keep an accountancy for third parties, represent the interests of third parties in court, advise the customer on many issues, and evaluate various aspects of its activities, conduct professional training, etc. As a result currently we have near one thousand Accountancy Firms in Ukraine.

As can be seen from the figure 1 in Ukraine there is an uneven diversification and quasi-competition of the financial services market. Significantly, more audit companies are located in Kyiv region, and as a result, the share of financial services there is also the largest, near 83 percent of total volume. 
The basement for this is that large companies, which are mainly located in Kyiv, are in high demand for their services from the side of big business. This was especially evident in the early 1990's in the context of mass privatization of state-owned enterprises.

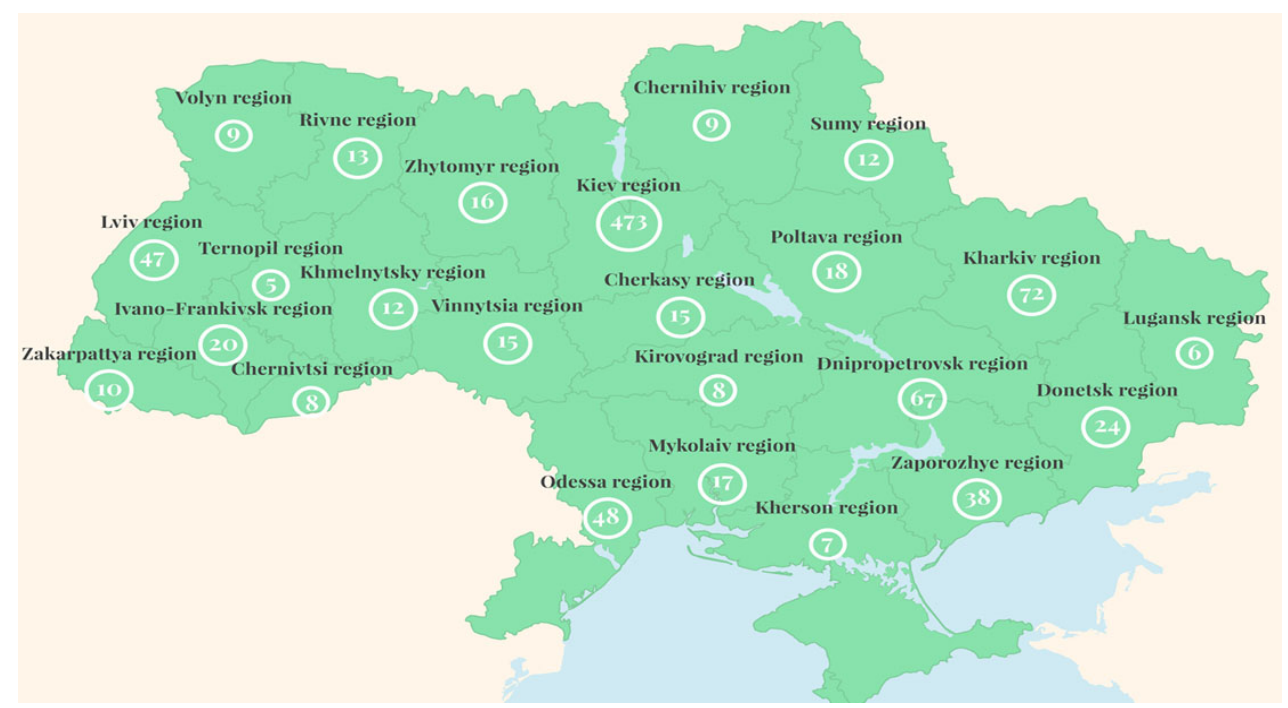

Fig. 1. Number of Accountancy Firms in Ukraine (28.12.2018)

Source: Created by author based [12].

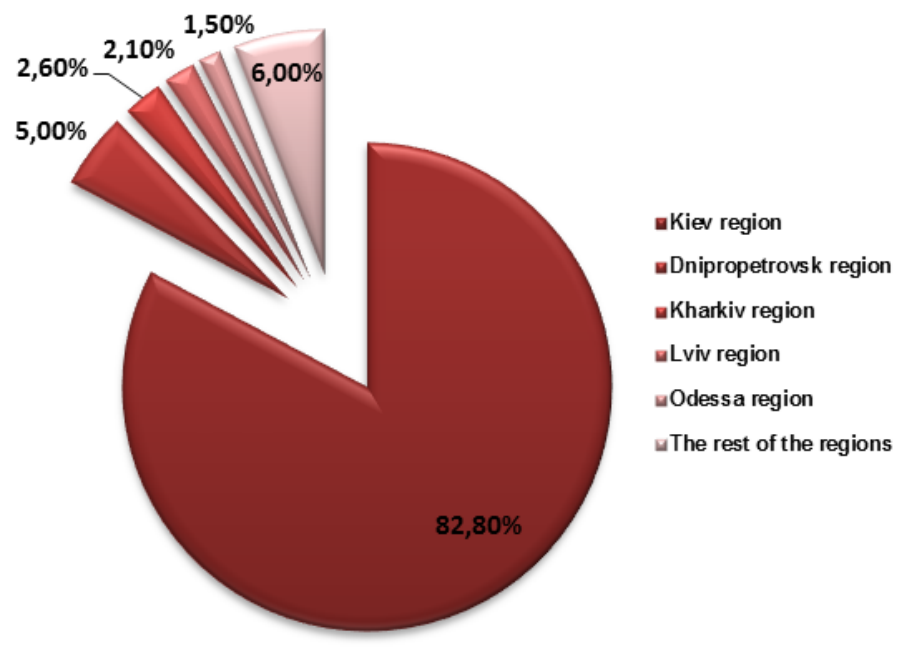

Fig.2. The share of professional services provided in Ukraine, 01.01.2018

Source: Created by author based on [12]. 
Top 10 of Global Accountancy Firms in 2019

\begin{tabular}{|c|c|c|c|c|}
\hline Rank & Firm & $\begin{array}{c}\text { Revenue, } \\
\text { \$ Bn }\end{array}$ & $\begin{array}{c}\text { Availability in } \\
\text { Ukraine }\end{array}$ & City of representatives \\
\hline $\mathbf{1}$ & Deloitte & 38,8 & $\checkmark$ & Kiev \\
\hline $\mathbf{2}$ & PwC & 37,7 & $\checkmark$ & Kiev, Dnipro, Lviv \\
\hline $\mathbf{3}$ & EY & 31,4 & $\checkmark$ & Kiev \\
\hline $\mathbf{4}$ & KPMG & 25,4 & $\checkmark$ & Kiev, Lviv \\
\hline $\mathbf{5}$ & BDO & 8,1 & $\checkmark$ & Kiev, Dnipro, Lviv, Odessa, \\
Kharkiv
\end{tabular}

There are couple essential reasons for the importance of providing high-level and quality professional services in Ukraine [15-17]:

- Country has high levels of economic and political risk and a very high level of financial system;

- High level of the corruption - (Corruption Perception Index - rank 131 out of 176 countries). Regarding the evolution of corruption over time, Ukraine has witnessed no improvement over the last 10 years;

- Low rating in Global Competitiveness Rankings (140 research countries) : Institutions - 134 rank, including : Public institutions - 130, Private - 110;

- Macroeconomic environment - 134 rank, including : Government budget balance $\%$ GDP - 104, Gross national savings - 124, Inflation - 134, Government debt - 110;

- Financial market development - 121 rank, including : Efficiency - 113, Trustworthiness and confidence -120 ;

- Rankings on Doing Business - 52 rank out of 176 countries in the case of Starting a Business.

Main trends of Market of Financial Services in Ukraine we can investigate from figures below.

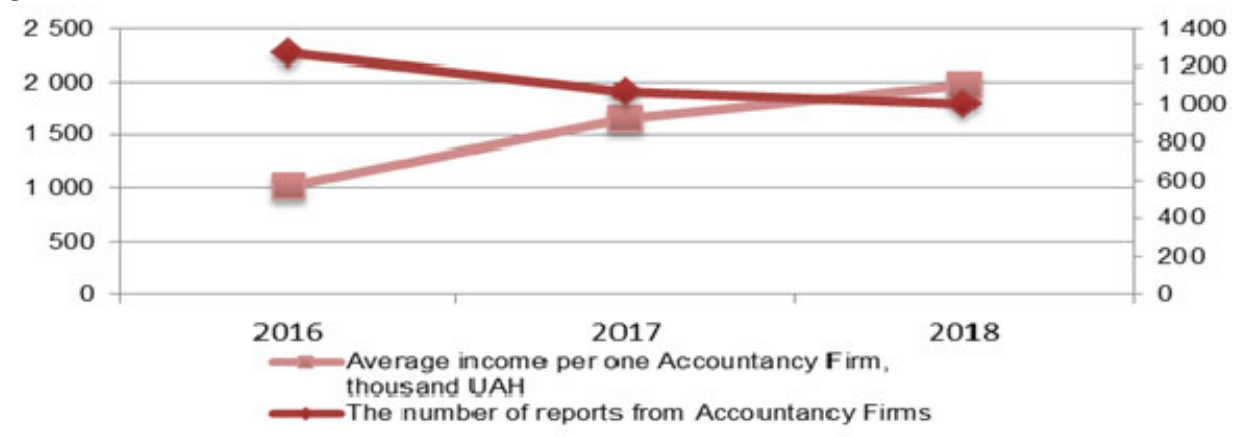

Fig. 3. The main trends in the market of professional services in Ukraine in 2016-2018

Source: created by author based [12]. 
Research point to a trend regarding constant decrease of the number of subjects of entrepreneurial activity and steady increase of their income, which can be explained also by the inflationary processes which occur in the economy of the country. Nonetheless, the number of audit companies has been closed in recent years, their income has increased.

Auditors (audit firms) can also provide other audit services related to their professional activities, in particular, on maintaining and restoring accounting, in the form of consultations on accounting and financial reporting, expertise and assessing the state of financial and economic activity and other types of economic and legal provision of economic activities of economic entities.

The number of professional services provided in Ukraine (at the beginning of each year)

\begin{tabular}{|c|c|c|c|c|c|c|}
\hline \multirow{2}{*}{ Indicator } & \multicolumn{3}{|c|}{ Thousand UAH } & \multicolumn{3}{|c|}{$\%$} \\
\hline & 2016 & 2017 & 2018 & 2016 & 2017 & 2018 \\
\hline $\begin{array}{c}\text { Total services provided } \\
\text { in Ukraine }\end{array}$ & 1291811,8 & 1761202,6 & 1973102,3 & 100 & 100 & 100 \\
\hline $\begin{array}{c}\text { Audit and other } \\
\text { assurance } \\
\text { (initiative and } \\
\text { obligatory audit, review } \\
\text { of a historical financial } \\
\text { information) }\end{array}$ & 602812,1 & 771840,1 & 847171,1 & 46,7 & 43,8 & 42,9 \\
\hline $\begin{array}{c}\text { Related services } \\
\text { (implementation of } \\
\text { agreed procedures, } \\
\text { preparing a financial } \\
\text { information) }\end{array}$ & 128445,2 & 125215,1 & 125031,9 & 9,9 & 7,1 & 6,4 \\
\hline $\begin{array}{l}\text { Other professional } \\
\text { services (accounting, } \\
\text { consulting services, } \\
\text { representation of the } \\
\text { customer's interests in } \\
\text { accounting, auditing, } \\
\text { taxation in public } \\
\text { authorities, } \\
\text { organizations or in } \\
\text { court) }\end{array}$ & 559701,9 & 861244,7 & 998564,4 & 43,3 & 48,9 & 50,6 \\
\hline $\begin{array}{l}\text { Organizational and } \\
\text { methodological } \\
\text { provision of audit } \\
\text { (conducting of } \\
\text { professional trainings } \\
\text { and development of } \\
\text { methodical materials, } \\
\text { implementation of } \\
\text { quality control of audit } \\
\text { services) }\end{array}$ & 852,6 & 2902,7 & 2334,9 & 0,1 & 0,2 & 0,1 \\
\hline
\end{tabular}

Source : compiled and calculated by author based [12].

Audit and other assurance (initiative and obligatory audit, review of a historical financial information) and other professional services (accounting, consulting services, 
representation of the customer's interests in accounting, auditing, taxation in public authorities, organizations or in court) are mostly provided in Ukraine (totally near 90-93\% during last three years) by accountancy firms than related services, and organizational and methodological provision of audit.

After deep research of a number of sources for assessing the Ukrainian economy [1521], we have developed an analysis that reflects both the strengths and weaknesses of the market for audit services.

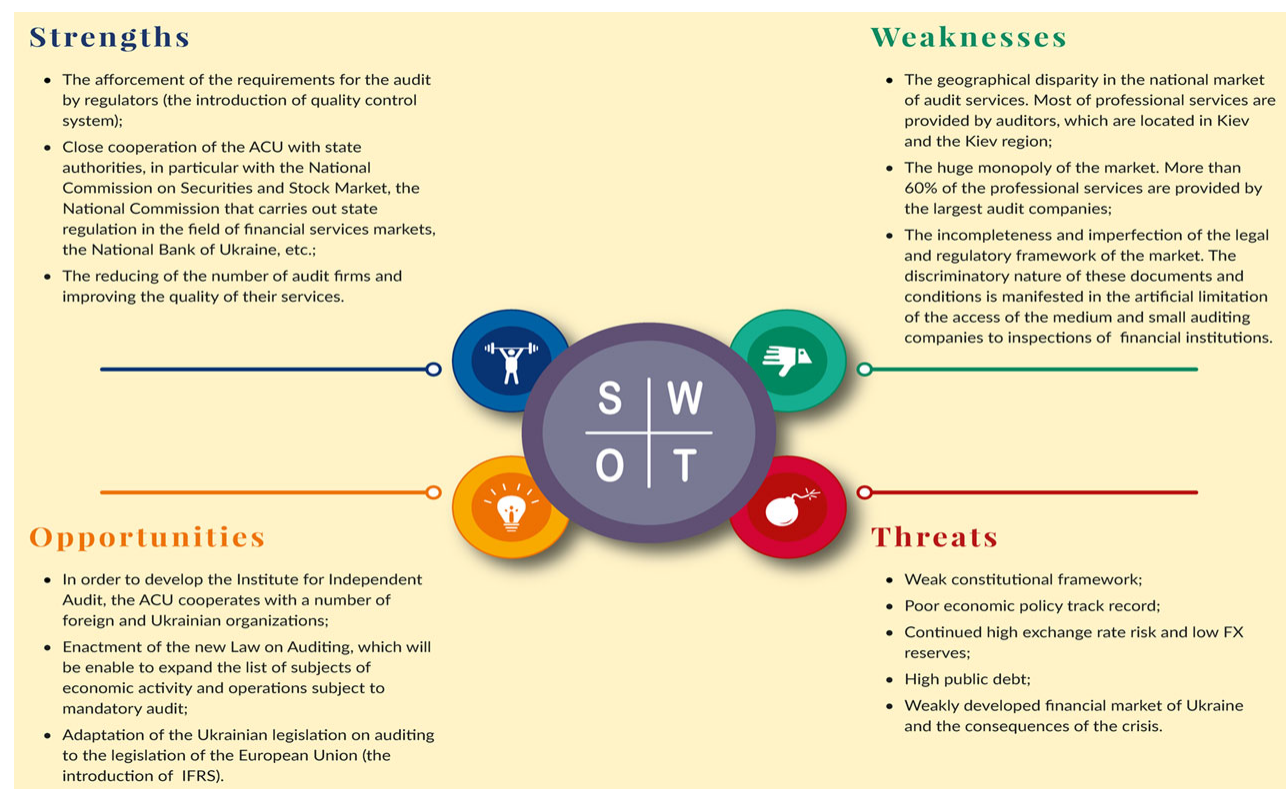

Fig.4. S.W.O.T. analysis on the market of professional services in Ukraine

Considering the peculiarities of the organization of audit activities and the construction of the market of audit services of the countries of the European Union as a whole, today it is necessary for Ukraine [19, 20]:

- to prepare the domestic market of audit services for its entry and cooperation with the market of the European Union;

- orientation of the state policy on increase of competitiveness, organizational and financial independence of Ukrainian auditors, prevention of monopolization of the market of audit services by foreign companies;

- the use of special innovative technologies by auditors and audit firms, information storage systems, the active use of electronic technologies aimed at automation and simplification of the interaction between auditors and the subject of verification, accelerating the introduction of an electronic exchange system between government and non-governmental institutional agents.

Taking into account the above, one can conclude that the market of audit services in Ukraine is characterized by high monopolization and quasi-competition.

The largest share of the market of audit services is presented in Kiev region. While in some regions this part is scanty. Unfortunately, large companies took a dominant position at the beginning of the development of Ukraine's independence, and held up to their position till nowadays. In such circumstances, comprehensive measures should be taken to 
regulate the market by the Antimonopoly Committee of Ukraine and the Audit Chamber. Consequently, improving the quality of leasing to new accreditation companies will lead to a higher degree of trust in them from the Ukrainians.

Ukraine on the way to Europe faces challenges of building a full-fledged, transparent and reliable financial market. A financial market should meet world standards, as audit services for decades are one of the most important parts of the financial market worldwide. Making changes in the legislation on regulating professional services, carrying out a complex independent, external evaluation of the legal basis for the functioning of audit companies, and organizing institutional changes in the direction of increasing market diversification - this is the basis for building a strong market for professional services in Ukraine.

1. Nexia International [Electronic resource]. - Access mode: https://nexia.com/

2. Nexia DK [Electronic resource]. - Access mode: http://dk.ua/

3. Deloitte Ukraine[Electronic resource]. - Access mode: https://www2.deloitte.com/ua/

4. PwC Ukraine [Electronic resource]. - Access mode: https://www.pwc.com/ua/

5. EY Ukraine [Electronic resource]. - Access mode: http://www.ey.com/ua/

6. KPMG [Electronic resource]. - Access mode: https://home.kpmg.com/ua/ru/home.html

7. BDO Ukraine [Electronic resource]. - Access mode: https://www.bdo.ua/uk-ua/

8. Grant Thornton [Electronic resource]. - Access mode: http://www.grantthornton.ua/ua/

9. RSM Ukraine [Electronic resource]. - Access mode: https://www.rsm.global/ukraine/uk

10. Crowe Horwath International Ukraine [Electronic resource]. - Access mode: http://www.crowehorwath.net/UA/about/Crowe_Horwath_AC_Ukraine.aspx

11. Baker Tilly International Ukraine [Electronic resource]. - Access mode: http://www.bakertilly.ua/

12. The Audit Chamber of Ukraine [Electronic resource]. - Access mode: http://www.apu.com.ua/

13. ICAS - The Institute of Chartered Accountants of Scotland [Electronic resource]. Access mode: https://www.icas.com/

14. IFAC [Electronic resource]. - Access mode: https://www.ifac.org/

15. Anti-corruption reforms in Ukraine - OECD Report, September, 2017 [Electronic resource]. - Access mode: http://www.oecd.org/corruption/acn/ACN-Ukraine-Round4-Monitoring-Report-ENG.pdf

16. The Global Competitiveness Report 2016-2017 - World Economic Forum, 2017 [Electronic resource]. - Access mode: http://www3.weforum.org/docs/GCR20162017/05FullReport/TheGlobalCompetitivenessReport2016-2017_FINAL.pdf

17. Economy Profile of Ukraine - Doing Business 2018 Indicators - World Bank Group [Electronic resource]. - Access mode: http://www.doingbusiness.org/ /media/wbg/doingbusiness/documents/profiles/country/ukr.pdf

18. Law of Ukraine "About Audit Activity" issued on April 24, 1993 [Electronic resource]. - Access mode: https://zakon.rada.gov.ua/laws/show/3125-12

19. Dolbnev D. Current state and directions improvement of the auditor activities in the conditions of the European integration of Ukraine and application international standards / D. Dolbnev // Economics and State. - 2018. - Vol.2. - P.72-76.

20. Dorosh N. Corporate social reporting as appendix to financial statement / N. Dorosh // Economics. 2015. - Vol. 10. - P. 17-23.

21. The European Union ENPI for Ukraine, December 2014. [Electronic resource]. Access mode: https://uba.ua/documents/doc/PULD/Final_Report_EN.pdf. 


\section{References}

1. Nexia International. nexia.com. Retrieved from https://nexia.com/

2. Nexia DK. dk.ua. Retrieved from http://dk.ua/

3. Deloitte Ukraine. www2.deloitte.com. Retrieved from https://www2.deloitte.com/ua/

4. PwC Ukraine. www.pwc.com. Retrieved from https://www.pwc.com/ua/

5. EY Ukraine. www.ey.com. Retrieved from http://www.ey.com/ua/

6. KPMG. home.kpmg.com. Retrieved from https://home.kpmg.com/ua/ru/home.html.

7. BDO Ukraine. www.bdo.ua. Retrieved from https://www.bdo.ua/uk-ua/

8. Grant Thornton. www.grantthornton.ua. Retrieved from http://www.grantthornton.ua/ua/

9. RSM Ukraine. www.rsm.global. Retrieved from https://www.rsm.global/ukraine/uk.

10. Crowe Horwath International Ukraine. www.crowehorwath.net. Retrieved from http://www.crowehorwath.net/UA/about/Crowe_Horwath_AC_Ukraine.aspx.

11. Baker Tilly International Ukraine. $\bar{w} w w \cdot b a k e r t i l l y . \bar{u} a$. Retrieved from http://www.bakertilly.ua/

12. The Audit Chamber of Ukrain. www.apu.com.ua. Retrieved from http://www.apu.com.ua/

13. ICAS - The Institute of Chartered Accountants of Scotland. www.icas.com. Retrieved from https://www.icas.com/

14. IFAC. $w w w$.ifac.org. Retrieved from https://www.ifac.org/

15. Anti-corruption reforms in Ukraine - OECD Report (2017, September). www.oecd.org. Retrieved from http://www.oecd.org/corruption/acn/ACN-Ukraine-Round-4Monitoring-Report-ENG.pdf

16. The Global Competitiveness Report 2016-2017 - World Economic Forum (2017). www3.weforum.-org. Retrieved from http://www3.weforum.-org/docs/GCR20162017/05FullReport/TheGlobalCompetitivenessReport2016-2017_FINAL.pdf.

17. Economy Profile of Ukraine - Doing Business 2018 Indicators - World Bank Group (2018). www.doingbusiness.org. Retrieved from http://www.doingbusiness.org/ / media/-wbg/doingbusiness/ documents/ profiles/ country/ ukr.pdf

18. Federalnyi zakon "Pro audytorsku diialnist" [Federal Law "About Audit Activity"]. (n.d.): zakon.rada.gov.ua. Retrieved from https://zakon.rada.gov.ua/laws/show/312512 [in Ukrainian].

19. Dolbnieva, D.V. (2018) Suchasnyi stan i napriamy udoskonalennia audytorskoi diialnosti v umovakh yevropeiskoi intehratsii Ukrainy ta zastosuvannia mizhnarodnykh standartiv [Current state and directions improvement of the auditor activities in the conditions of the European integration of Ukraine and application international standards]. Ekonomika ta derzhava - Economics and State, 3, 73-76 [in Ukrainian].

20. Derun, N. (2015) Korporatyvna sotsialna zvitnist yak dodatok do finansovoi zvitnosti [Corporate social reporting as a supplement to financial reporting]. Ekonomika Economics, 10, 17-23 [in Ukrainian].

21. The European Union ENPI for Ukraine, December 2014. Retrieved from https://uba.ua/documents/doc/PULD/Final_Report_EN.pdf. 


\section{АНАЛІЗ РИНКУ ПРОФЕСІЙНИХ ПОСЛУГ В УКРАЇНІ н. Жмурко \\ Львівський національний університет імені Івана Франка 79008, м. Львів, проспект Свободи, 18 e-mail:nata_zhmurko@ukr.net}

Розглянуто необхідність та важливість існування ринку професійних послуг, окреслено суть та призначення аудиту відповідно до чинного законодавства України, функції та роль аудиторської палати. Висвітлено особливості нормативно-правової та інституційної основи надання послуг аудиторськими фірмами в розрізі міжнародного та вітчизняного законодавства. Проаналізовано наявність в Україні найбільших світових аудиторських компаній, виявлено представництво кожної із десяти фінансових гігантів на вітчизняному ринку. Окреслено історичне та інституційне підгрунтя для формування несправедливого конкурентного середовище в цій галузі, де найбільша частка припадає саме на великі аудиторські компанії. Досліджено причини монополізації ринку надання аудиторських послуг та окреслено чинники, які перешкоджають становленню та функціонуванню малих аудиторських компаній. Проведено аналітичний огляд аудиторської діяльності в державі в розрізі областей та видів надання послуг. На основі аналізу виявлено, що ринок надання аудиторських послуг диверсифікований нерівномірно на всій території України, зокрема найбільша частка всіх аудиторських компаній припадає на Київську область, де зосереджено майже половина усіх учасників ринку професійних послуг держави. На основі оцінки даних протягом останніх трьох років, виявлено низку проблем, з якими стикається ринок професійних послуг в Україні. На основі проведеного аналізу, автором розроблено S.W.O.T. аналіз українського ринку професійних послуг. В проведеному аналізу чітко окреслено всі чотири ланки, а саме : сильні сторони ринку професійних послуг України, слабкі сторони надання аудиторських послуг, потенційні можливості для функціонування даного ринку як в межах України так і міжнародному ринку, а також перешкоди 3 якими протягом останніх років і на сьогодні ринку аудиторських послуг доводиться перебувати. Доведено, що несприятлива соціально-економічна ситуація, що склалась в Україні вимагає якісного надання аудиторських послуг, а також розроблення інституційно-правового середовища та умов яке сприятиме рівному та справедливому розподілу надання фінансових послуг у державі.

Ключові слова: аудит, фінансові (аудиторські) послуги, ринок професійних послуг, аудиторські компанії, S.W.O.T. аналіз. 